\title{
Impact of Moving to Online Learning on the Way Educators Teach
}

\author{
Peter GM de Jong ${ }^{1}$
}

Published online: 17 July 2020

(C) International Association of Medical Science Educators 2020

All of a sudden healthcare education faced huge challenges in response to the COVID-19 pandemic. Schools were closed and students sent home, and exams were postponed or canceled. Student research projects were put on hold as access to the research facilities was denied. And most of all, clinical teaching was postponed immediately to protect students and patients from further contamination. From one day to the next, the ever-crowded and lively buildings of schools and universities became dead quiet.

As the only logical solution, schools started rapidly transitioning towards remote online learning with a focus on teaching and learning activities without any need for physical presence. And although computer-based and online learning has been around for decades, it wasn't easy to implement a campus-wide transition on such short notice. Taskforces for distance learning were appointed, and through technical and organizational trial and error, lectures were transformed into webinars and small group sessions into virtual classrooms. Due to the limited amount of time available, efforts were mainly focused on activities that can be implemented quickly $^{1}$. In fact schools entered an emergency remote teaching mode in order keep their students going ${ }^{2}$.

Very quickly educators began to realize that online teaching is not equivalent to simply copying the regular face-toface teaching modes into online ones. Online teaching is a completely different instruction concept that requires different skills that many educators haven't developed and support that many institutions don't provide. Take, for example, the large classroom lecture. Typically, we train our educators on presenting in front of the classroom, speaking clearly, designing effective PowerPoint presentations, implementing engaging elements like quizzes, and moderating questions and answers from the audience. In the online classroom, the educator is

Peter GM de Jong

P.G.M.de_Jong@lumc.nl

1 Leiden University Medical Center, Leiden, Netherlands sitting at home, staring into the computer screen watching a virtual lecture hall where hundreds of students are logged in but cannot be seen. During the session the teacher hardly gets direct student feedback and has no idea if the students are still listening, understanding, or even being connected. During the lecture a flood of questions appear in the Q\&A chat creating the daunting task of keeping up. Not to mention how to deal with all the social aspects that are typically involved in the traditional educator-learner relationship.

Moving forward, I feel we need to do two things: first, we will need to redesign our curriculum. Is an online large group lecture an effective learning activity to begin with, or should we look for different modalities to implement? As indicated in the model of Puentedura, we urgently need to bring technology-enhanced learning from the lower levels of substitution and augmentation of existing teaching into real modification and redefinition ${ }^{3}$. We need to stop replacing existing lectures and practical sessions with identical online versions with preferably the same characteristics. We need to transform passive online readings and videos into interactive and gamebased learning. We need to start redeveloping the curriculum based on the didactical principles of technology-enhanced learning.

Second, as an immediate result of this transformation, the role of the educator in health sciences education needs to be redefined one more time. As we were already transitioning from an instructor-of-knowledge model towards a facilitatorof-learning model, now we need to take one step further towards the online learning facilitator. We need to start developing our faculty with the required didactical skills to effectively run an online curriculum and provide them with adequate professional competences and organizational support for this new online learner-centered environment.

Maybe for healthcare education, we should not see the pandemic as a threat, but as an opportunity. The real challenge we face is to improve our educational system through enhanced faculty development and scholarship of teaching and learning to be able to face the inevitable global challenges of the future. As medical science educators we have the 
responsibility to keep working on the advancement of the field of health sciences education, and therefore I call for educators to share their experiences and new developments in these disturbing times in our journals and at our (virtual) conferences.

\section{References}

1. Sandars J, Correia R, Dankbaar M, de Jong P, Goh P, Hege I, Masters K, Oh S, Patel R, Premkumar K, Webb A, Pusic M. Twelve tips for rapidly migrating to online learning during the
COVID-19 pandemic. MedEdPublish https://doi.org/10.15694/ mep.2020.000082.1, 2020

2. Hodges CB, Moore S, Lockee BB, Trust T, Bond MA. The difference between emergency remote teaching and online learning. EducauseReview. March 27, 2020. https://er.educause.edu/articles/ 2020/3/the-difference-between-emergency-remote-teaching-andonline-learning

3. Puentedura, RR (2013). SAMR: Moving from enhancement to transformation [Web log post]. Retrieved from http://www.hippasus.com/ rrpweblog/archives/000095.html

Publisher's Note Springer Nature remains neutral with regard to jurisdictional claims in published maps and institutional affiliations. 